\title{
Terpenoid Resin Distribution in Conifer Needles with Implications for Red Tree Vole, Arborimus longicaudus, Foraging
}

\author{
Rick G. Kelsey ${ }^{1}$, ERic D. Forsman ${ }^{1}$, and JAmes K. Swingle ${ }^{2}$ \\ ${ }^{1}$ USDA Forest Service, Pacific Northwest Research Station, 3200 SW Jefferson Way, Corvallis, Oregon 97331 USA \\ ${ }^{2}$ Department of Fisheries and Wildlife, Oregon State University, Corvallis, Oregon 97331 USA
}

Kelsey, Rick G., Eric D. Forsman, and James K. Swingle. 2009. Distribution of terpenoid resins in conifer needles and their implications for Red Tree Vole, Arborimus longicaudus, foraging. Canadian Field-Naturalist 123(1): 12-18.

Tree voles are dietary specialists, feeding almost exclusively on conifer needles and bark. They reduce their exposure to conifer chemical defenses by physically removing resin ducts from many needles before ingesting the remaining tissue. The portion of needle removed differs among tree species, depending on the location of the resin ducts. To evaluate the amount of resin avoided by this behavior we removed the resin ducts from Douglas-fir, Western Hemlock, and Sitka Spruce needles and used gas chromatography to compare volatile resin concentrations in needles with and without the resin ducts removed. Needle tissues without resin ducts contained no terpenoid resin, demonstrating that tree voles can regulate the nutritional quality of their diet by controlling the amount of resin ingested. We suggest that differences in the physical structure (and possibly chemical composition of terpenes) of the needles make it difficult for voles to easily switch between tree hosts.

Key Words: Red Tree Vole, Arborimus longicaudus, terpenoid resins, resin ducts, plant-herbivore interactions, Oregon.

Foliar terpenoid resins of conifers are synthesized and stored in resin ducts. Like other plant secondary metabolites, they function as a chemical defense against pathogens and herbivores (Langenheim 2003; Stamp 2003; Dearing et al. 2005). Because these compounds are unpalatable, toxic, or impair metabolizable energy intake (Dearing et al. 2005; Iason 2005; Sorensen et al. 2005), there are relatively few mammals that live primarily on a diet of conifer needles. Notable exceptions include the Stephens' Woodrat (Neotoma stephensi) which feeds primarily on juniper foliage (Vaughan 1982), and the Woolly Flying Squirrel (Eupetaurus cinereus) in northern Pakistan which feeds primarily on pine needles (Zahler and Khan 2003).

The tree voles (Red Tree Vole, Arborimus longicaudus, Sonoma Tree Vole, A. pomo) of western Oregon and northwestern California are also an exception in that they live in the canopy of coniferous trees and are dietary specialists, feeding almost exclusively on conifer needles and bark (Taylor 1915; Benson and Borell 1931; Hamilton 1962). Tree voles harvest their food at night, cutting off the tips of branches and transporting them back to the nest. Fresh cuttings are stored inside or on top of nests, thereby eliminating the need to forage during the day and allowing them to reduce their exposure to diurnal predators (Howell 1926). The cuttings are typically $2-30 \mathrm{~cm}$ long and consist primarily of needles from the current or previous year (E. Forsman, unpublished data). Tree voles obtain water from the internal water content of conifer needles and bark, and have also been observed in captivity to lick water droplets off needles and other surfaces (Clifton 1960; Maser 1998). In addition to being the only truly arboreal Microtine rodent, tree voles are an important food source for many small mammals and birds, in- cluding weasels and owls (Forsman et al. 1984, 2004; Graham and Mires 2005; Swingle 2005). While they are primarily a resident of Douglas-fir (Pseudotsuga menziesii) forests, a small subset of the tree vole population in coastal northwest Oregon live and feed almost exclusively in forests of Western Hemlock (Tsuga heterophylla) and Sitka Spruce (Picea sitchensis) (Walker 1928, 1930; Clifton 1960). Occasionally they will utilize Grand fir (Abies grandis), Bishop Pine (Pinus muricata) or Monterey Pine (Pinus radiata) canopies for food and nesting sites, especially in California (Wooster and Town 2002; Forsman and Swingle unpublished data, L. Diller personal communication).

One reason tree voles can exist on a diet of conifer needles is that they physically remove the resin ducts from many of the needles they consume, thereby regulating or reducing the amount of terpenoid resin ingested, and thus partially controlling the digestibility and nutritional quality of their diets (Howell 1926; Maser et al. 1981; Iason 2005; Iason and Villalba 2006). Douglas-fir needles contain two resin ducts near the outer margins (Figure 1). To remove them, tree voles bite off one needle at a time, hold it in their front feet and rapidly pass it sideways through the mouth, using their incisors to bite off a thin, longitudinal strip of tissue from the outer edge containing the resin duct. Then, they flip the needle over and repeat the process on the opposite edge. After removing both resin ducts, they eat the center portion of the needle (Howell 1926; Benson and Borell 1931). The average amount of time required for the entire process was 11.5 seconds for a vole we observed in captivity. The hair-like strands of tissue containing intact resin ducts are either discarded or used for nest material. 
The feeding behavior of tree voles on Western Hemlock or Sitka spruce needles differs. Western hemlock needles have a single longitudinal resin duct running along the midrib (Figure 1), which the voles discard after eating the needle margins on both sides (Clifton 1960). Sitka Spruce has irregularly distributed, discontinuous resin ducts that are sometimes missing entirely or are concentrated in the basal half of the needle (Figure 1; Weng and Jackson 2000). We have limited observations of a captive vole that often browsed off the needle tips of Sitka Spruce, leaving the basal half were resin ducts are more common, uneaten. There are several cases in which we or others (Clifton 1960) have found small numbers of spruce resin ducts in vole nests, removed from the needle edges in the same way they are removed from Douglas-fir.

Although it is well known that tree voles reduce their exposure to terpenoid resins in conifer needles by physically removing the resin ducts where the terpenoids are concentrated, to our knowledge it is not known if this behavior allows them to avoid these compounds altogether, or only partially, if some portion of the volatile terpenes occur outside of the resin ducts. Herein, we describe a study in which we compared the resin content of whole needles to needles in which we surgically removed the resin ducts in a manner similar to the feeding behavior of tree voles. Our objective was to evaluate the effectiveness of resin duct removal in allowing voles to avoid ingestion of terpenoid resins in their diet.

\section{Methods and Materials \\ Plant Material}

Since some tree voles are known to spend their entire life in a single old growth tree (Swingle 2005), we sampled one tree of each species in the spring of 2006 in western Oregon. The trees sampled included a $56 \mathrm{~cm}$ dbh Douglas-fir $4.0 \mathrm{~km}$ northwest of Corvallis, Benton County $\left(44.5820^{\circ} \mathrm{N}, 123.3474^{\circ} \mathrm{W}\right)$, and a $42 \mathrm{~cm}$ dbh Western Hemlock and $59 \mathrm{~cm}$ dbh Sitka spruce located $1.9 \mathrm{~km}$ north of Siletz, Lincoln County $\left(44.7383^{\circ} \mathrm{N}, 123.9150^{\circ} \mathrm{W}\right)$. In each tree we collected 6 cuttings that were $30-50 \mathrm{~cm}$ long from the ends of different branches. Timing of collections was 10-14 April (Douglas-fir), 17-20 April (Western Hemlock), and 8-15 May (Sitka Spruce). The cut ends were wrapped with wet paper towels and transported to the laboratory, where they were shortened, if needed, to fit inside one gallon plastic bags. The open bags were stored in a dark $7^{\circ} \mathrm{C}$ coldroom with a wet paper towel around the cut end, and near the bag opening, to keep the needles moist. Current-year needles were removed from the branches and processed for analysis within 48-54 hrs of entering the coldroom, except for one pair of Sitka Spruce needles sampled at 72-78 hrs and another pair at 96-102 hrs.

\section{Needle Sampling and Processing}

Needles were sampled the same way for all three conifers. We removed five needles in close proximity
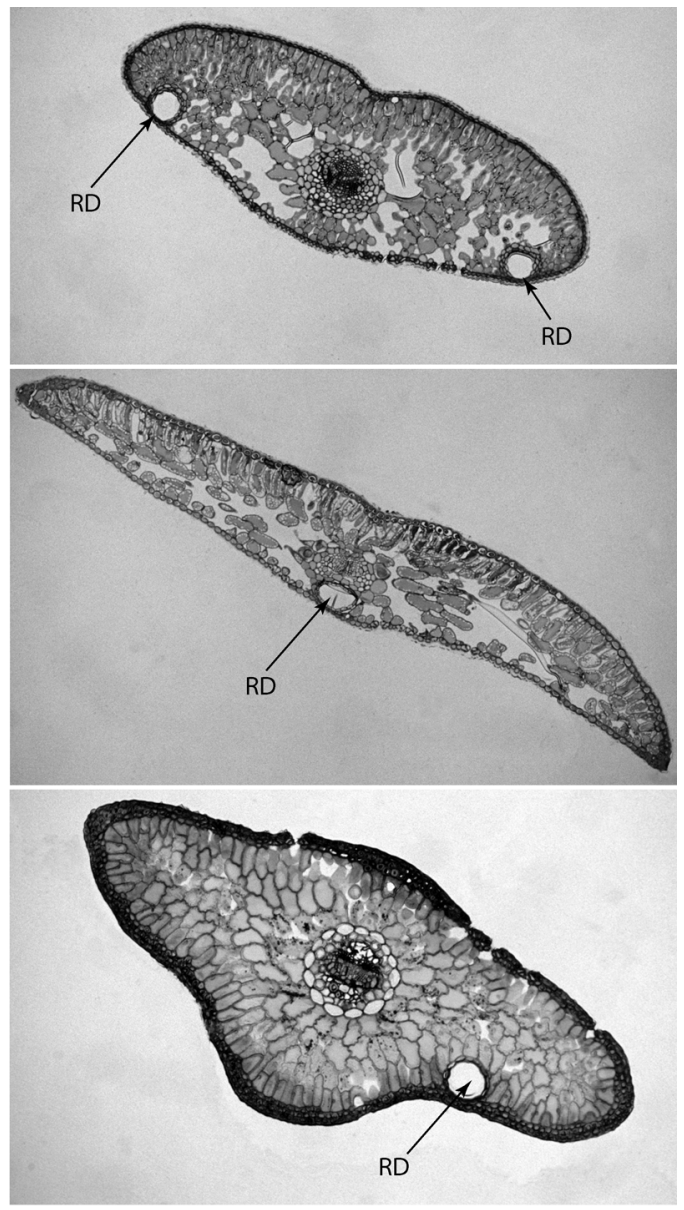

FIGURE 1. Photomicrographs of transverse cut conifer needles showing the location of resin ducts in Douglas-fir, top; Western Hemlock middle; and Sitka Spruce, bottom.

to one another from the branch cutting and randomly selected one of them for removal of the resin ducts. The remaining four were used to estimate needle water content by combining and weighing them in a small vial, then heating in a $102^{\circ} \mathrm{C}$ oven for $45-60$ min to stop metabolic activity. The single needle then was weighed, cut, extracted, and analyzed as described below. When the analyses of all portions of the cut needle were complete, a second group of five needles was sampled from the same part of the branch as the first group. One was randomly selected for extraction without removing the resin ducts (i.e., whole) and the other four were used to estimate water content. When the gas chromatograph analysis of the whole needle extract was complete, this sampling scheme was repeated at another location on the same cutting, or on a different branch. When sampling was completed for the day, the needles selected for water content estimation were dried in the $102^{\circ} \mathrm{C}$ oven for $16 \mathrm{hrs}$, cooled in a desiccator box, and reweighed. Ten replicates of 
dissected and whole needles were sampled from the six branch cuttings, with no more than two pairs from each branch.

\section{Needle Cutting and Extracting}

Douglas-fir needles, viewed in cross section, have an upper and lower surface, with a vascular cylinder down the midrib and a pair of longitudinal resin ducts along the outer edges of the needle (Figure 1; Apple et al. 2002). The resin ducts extend nearly the entire needle length. To remove the ducts, we taped the needle onto a dissecting microscope stage with the abaxial surface up and rows of white stomata clearly visible. Then, we used a single-edge razor blade to make longitudinal cuts on each side of the midrib following the mid to outside lines of stomata parallel to the leaf margins. This removed thin strips of tissue containing the resin ducts that were combined in a sealed $1.5 \mathrm{~mL}$ vial. The inner, midrib portion of the needle (without resin ducts) was placed in a separate, capped vial. Ethyl acetate (200 $\mu \mathrm{L}, 99.9 \%)$ containing carvacrol (TCI America) as an internal standard was added to the tissue sample with resin ducts, and the tissue was crushed and cut with a sharp metal spatula for about $60 \mathrm{sec}$, then allowed to extract for $5 \mathrm{~min}$. Two $\mu \mathrm{L}$ of this extract was injected immediately into the gas chromatography. When this analysis was complete, the vial containing the midrib portion of the needle was processed in the same manner. Then, another adjacent set of five needles was sampled and processed as above, except the whole single needle was crushed and extracted without removing the resin ducts.

In cross section, Western Hemlock needles have an upper and lower surface with a single resin duct that runs the length of the needle midrib, below the central vascular cylinder (Figure 1). To remove this duct, we taped each needle with the abaxial surface up and made a longitudinal cut along each side of the midrib with a single-edge razor blade. The midrib portion with the resin duct was placed in a vial and extracted and analyzed like the Douglas-fir, using $100 \mu \mathrm{L}$ of ethyl acetate containing carvacrol as an internal standard. The two strips of needle tissue from either side of the midrib were combined immediately in a sealed vial and further processed after analysis of the midrib tissue was complete.

Sitka spruce needles in cross-section have a shape similar to Douglas-fir, with a pair of resin ducts about midway between the midrib and the margins. However, the resin ducts of Sitka Spruce do not span the length of the needle; they are discontinuous and can be more like sacs, or may not be present at all (Figure 1; Weng and Jackson 2000). To help document this variability, the needle selected for cutting was partitioned into four quarters by first dividing it in half along the midrib. The right half of the needle was sealed in a vial and held for later processing. The left half then was cut at the longitudinal center to yield the apical left and basal left quarters. These were sealed immediately in vials and the basal quarter held for extraction until the gas chromatography became available following analysis of the apical segment. When analysis of the left quarters was done, the right half of the needle was processed the same way. Because of their small size, these quarter needle segments were extracted with $50 \mu \mathrm{L}$ of ethyl acetate containing carvacrol as an internal standard, while the whole needle sample was extracted with $100 \mu \mathrm{L}$ of ethyl acetate containing carvacrol.

\section{Gas Chromatography}

We quantified volatile constituents in the extracts using a Hewlett Packard 5890 Series II gas chromatograph with a flame ionization detector and Phenomenex ZB-5 column $(30 \mathrm{~m} \times 0.25 \mathrm{~mm} \times 0.25 \mu \mathrm{m}$ film thickness). Helium was the carrier gas, with a $1.0 \mathrm{~mL} /$ min flow through the column at $60^{\circ} \mathrm{C}$ and a $1: 10$ split. Injector and detector temperatures were $250^{\circ} \mathrm{C}$. The oven program started at $60^{\circ} \mathrm{C}$ with a $5^{\circ} \mathrm{C} / \mathrm{min}$ increase to $220^{\circ} \mathrm{C}$ with a $13 \mathrm{~min}$ final hold. Compound concentrations were calculated from the carvacrol internal standard using a 1:1 response factor, and expressed in $\mu \mathrm{g} /$ needle or needle segment and percent of needle dry weight.

Volatile compounds in the resins were identified by gas chromatography-mass spectrometry using the same instrument above with a 5970 mass selective detector $(70 \mathrm{eV})$, and $\mathrm{J} \& \mathrm{~W}$ Scientific DB-5 column (equivalent to the ZB-5 column above; $30 \mathrm{~m} \times 0.25 \mathrm{~mm} \times 0.25 \mu \mathrm{m}$ film thickness). Other operating conditions were as described. Each compound spectrum was verified with those in the Wiley library on the computer and with relative retention times and spectra reported by Adams (2007) for a DB-5 column. To get extracts with sufficient concentrations of resin for mass spectroscopy, we used a composite sample of needles from each species (10, 4, and 4 needles for Western Hemlock, Douglas-fir, and Sitka Spruce, respectively). The needles were cut into small pieces with a blade and extracted with $200 \mu \mathrm{L}$ of ethyl acetate. After soaking for $5.0 \mathrm{~min}, 2 \mu \mathrm{L}$ of the extract was immediately injected into the gas chromatography.

\section{Data Analysis}

Within each conifer species we used a $t$-test (Statgraphics $^{\circledR}$ Plus Ver. 5.1) to compare the means of resin concentrations in whole needles to the dissected portions of needles that contained the resin ducts (sum of the four quarters for Sitka Spruce). Each data set was checked and found to be normally distributed with homogeneous variances. Needle portions without resin ducts contained zero resin, with no variance, and therefore was not compared statistically to needle portions with resin ducts, or to the whole needles. We used $P \leq 0.05$ as the criterion for statistical significance. 
TABLE 1. Resin concentrations and dry weights (mean $\pm 1 \mathrm{SE}$ ) for needles of three conifer species used as forage by Red Tree Voles (Arborimus longicaudus) in western Oregon. For each species, resin concentrations are provided for whole needles and for portions of individual needles with resin ducts (+RD), or without resin ducts (-RD)

\begin{tabular}{lccc}
\hline \hline Species/needle portion & Resin $(\mu \mathrm{g} / \text { needle })^{1}$ & Whole needle dry wt $(\mu \mathrm{g})$ & Resin $(\%$ dry wt) \\
\hline Douglas-fir & $45.68 \pm 5.88^{\mathrm{a}}$ & & \\
$\quad$ Margins (+RD) & 0.00 & $5717 \pm 285$ & $0.77 \pm 0.04$ \\
Midrib (-RD) & $45.13 \pm 6.14^{\mathrm{a}}$ & & \\
Whole needle & 0.00 & $3511 \pm 189$ & $1.13 \pm 0.03$ \\
Western Hemlock & $39.00 \pm 3.14^{\mathrm{a}}$ & & \\
Margins (-RD) & $39.81 \pm 2.98^{\mathrm{a}}$ & & \\
Midrib (+RD) & 0.00 & & \\
Whole needle & $0.05 \pm 0.05$ & & \\
Sitka Spruce & $51.73 \pm 11.21$ & & \\
Apex left quarter & $52.55 \pm 10.15$ & $6029 \pm 173$ & \\
Apex right quarter & $104.33 \pm 20.91^{\mathrm{a}}$ & & \\
Base left quarter (+RD) & $86.93 \pm 12.69^{\mathrm{a}}$ & & \\
Base right quarter (+RD) & & & \\
Sum all 4 quarters (+RD) & & & \\
Whole needle &
\end{tabular}

${ }^{1}$ Statistical analyses were done separately within each species. Concentrations within species followed by the same letter were not significantly different $(P>0.05)$.

\section{Results}

Resins in dissected needles of Douglas-fir and Western Hemlock were found only in those portions where resin ducts were located, and their total resin content was the same as measured by whole needle extraction (Table 1). Those portions of needles without resin ducts contained no terpenoids. In the Sitka Spruce samples, there was no resin in the apical half of the needles, except for one with a small amount $(<<1 \%$; $0.46 \mu \mathrm{g})$ in the apical right quarter. This probably resulted from a slightly longer resin duct extending beyond the longitudinal mid-point. Mean concentrations of resins were the same in the Sitka Spruce basal left and right quarters, although there were two needles with extremely low amounts (1.66 and $0.43 \mu \mathrm{g})$ in the basal left side (Table 1). Sitka Spruce needles extracted whole had a slightly lower resin content than the total for needles cut into quarters, but the difference was not statistically significant. This difference was largely the result of one whole needle that contained almost no resin $(0.07 \mu \mathrm{g})$.

Although our experiment was not designed to statistically compare characteristics among conifer species, our results do suggest that there are differences among species that could influence the vole's selection of host species. Douglas-fir and Western Hemlock had similar quantities of resin per needle, but the total resin content in Sitka Spruce needles was much higher than Douglas-fir or Western Hemlock (Table 1). Western Hemlock needles had a lower dry weight biomass than those of Douglas-fir or Sitka Spruce, which were about the same (Table 1). Douglas-fir had the lowest resin concentrations calculated as a percentage of the needle dry weight $(0.77 \%)$, followed by Western Hemlock (1.13\%), and Sitka Spruce (1.69\%). The
Douglas-fir and Sitka Spruce resins each contained 13 volatile components $\geq 1 \%$, while Western Hemlock had 12 (Table 2). Volatile compounds in Douglasfir and Western Hemlock resins were all terpenoids (mono-, sesqui- and diterpenes). Sitka Spruce was the only species with non-terpenoid esters and no sesquiterpenes. There were four compounds ( $\alpha$-pinene, myrcene, limonene, and $\beta$-phellandrene) common to all three species, but in substantially different proportions (Table 1). In Douglas-fir, $\beta$-pinene, $\alpha$-pinene, and sabinene were the three most abundant components representing $66.40 \%$ of the resin. In Western Hemlock, limonene $\beta$-phellandrene, myrcene, and $\alpha$-pinene made up $60.90 \%$ of the resin, whereas myrcene, limonenel $\beta$-phellandrene, and piperitone made up $48.19 \%$ of the Sitka Spruce resin.

\section{Discussion}

Our results confirm that, by avoiding the resin ducts in conifer needles, tree voles are able to dramatically reduce the terpenoid contents of their diet. However, we have noticed that captive tree voles occasionally ingest whole needles, including the resin ducts. The exact proportion and variability of whole needles consumed is not known for any of the conifer hosts that we examined. There are numerous other mammalian herbivores that ingest resinous conifer tissues and preferentially select individual plants, plant parts, or chemically-mediated diets with lower concentrations of these compounds (Radwan et al. 1982; Snyder 1992; Kimball et al. 1998; Vourc'h et al. 2002). Many questions remain regarding the amount of resin ingested with whole needles, what impact the resin has on vole physiology, and what physiological mechanisms they use to process the resins. 
TABLE 2. Mean percentage composition of volatile compounds in the needle resin of three conifer species used for forage by Red Tree Voles (Arborimus longicaudus) in Oregon. ${ }^{1}$ Compounds are listed according to their retention times, and only those that comprised $>1 \%$ of the total integrated peak area within a species are shown.

\begin{tabular}{|c|c|c|c|}
\hline Compound & Douglas-fir & Western Hemlock & Sitka Spruce \\
\hline$\alpha$-Pinene & 12.47 & 14.53 & 1.17 \\
\hline Camphene & - & - & 1.01 \\
\hline Sabinene & 11.65 & - & - \\
\hline$\beta$-Pinene & 42.28 & 7.99 & - \\
\hline Myrcene & 2.07 & 15.63 & 33.10 \\
\hline$\alpha$-Phellandrene & - & 1.93 & 1.14 \\
\hline Limonene $\beta$-Phellandrene ${ }^{2}$ & 1.88 & 30.74 & 7.63 \\
\hline 1,8 -Cineole ${ }^{3}$ & - & - & 1.55 \\
\hline (z)- $\beta$-Ocimene & 1.29 & 5.73 & - \\
\hline Terpinolene & 5.13 & - & - \\
\hline Isopentyl isovalerate ${ }^{4}$ & - & - & 4.71 \\
\hline Ester C10? ${ }^{4}$ & - & - & 2.82 \\
\hline Camphor $^{3}$ & - & - & 2.74 \\
\hline Piperitone $^{3}$ & - & - & 7.46 \\
\hline Cirtonellyl acetate ${ }^{3}$ & 1.52 & - & - \\
\hline$\alpha$-Humulene & 3.33 & - & - \\
\hline Germacrene D & 3.51 & 1.61 & - \\
\hline$\gamma$-Cadinene & - & 1.56 & - \\
\hline$\delta$-Cadinene & - & 2.19 & - \\
\hline Sesquiterpene $\mathrm{C} 15^{5}$ & 4.40 & 2.10 & - \\
\hline Diterpenes $^{6}$ & $4.05(2)$ & $4.30(2)$ & $28.16(3)$ \\
\hline Cumulative Total & 93.58 & 88.31 & 91.50 \\
\hline Monoterpene hydrocarbon & 72.37 & 74.45 & 44.06 \\
\hline Monoterpene oxygenated & 5.92 & 2.10 & 11.75 \\
\hline Sesquiterpene hydrocarbon & 6.84 & 5.36 & - \\
\hline Sesquiterpene oxygenated & 4.40 & 2.10 & - \\
\hline Diterpenes & 4.05 & 4.30 & 28.16 \\
\hline Non-terpene esters & - & - & 7.53 \\
\hline
\end{tabular}

${ }^{1}$ Mean calculated from the 10 whole and 10 cut needles of each species, since cutting the needles would not impact their resin composition.

${ }^{2}$ Both compounds present in all three species.

${ }^{3}$ Oxygenated monoterpene.

${ }^{4}$ Non-terpene ester (oxygenated).

${ }^{5}$ Oxygenated sesquiterpene, possibly an isomer of germacrene D-4-ol.

${ }^{6}$ The diterpenes were not identified, but were all different among the three species, with the number of compounds $\geq 1 \%$ in parentheses.

The terpene resins that tree voles ingest in whole needles likely contribute to host recognition and reinforcement of their strong host specificity. We and others (Walker 1930; Clifton 1960; M. Johnson, unpublished notes) have noted that captive tree voles raised from infancy on one species of conifer may reject needles from other species and may starve if suddenly switched to a diet of needles from an unfamiliar species. Tree voles are coprophageous and the young ingest fecal pellets from their mother before their eyes open (Hamilton 1962). Passage of host terpenes from mother to offspring in fecal matter could be the initial step in developing host specificity or possibly insuring gut inoculation with microbes that help metabolize the resin. In addition, needle sizes and shapes among conifer species are similar but not identical, and as shown here the resin ducts are located in different positions. Having learned from their mother how to feed on a particular species with discrete needle characteristics, tree voles are unable to learn quickly how to feed on a different species.

The thin strips of Douglas-fir tissue containing resin ducts are typically used by the voles as building material for their nests (Howell 1926; Maser et al. 1981), whereas nest building from the same needle tissues of Western Hemlock and Sitka Spruce nest is more variable. Male European Starlings (Sturnus vulgaris) comingle fresh herb tissues rich in volatile compounds into their nests, resulting in fewer bacteria, no adverse impact from mites, and fledglings with greater body mass compared to nests without these herbs (Gwinner and Berger 2005). It is unknown whether vole nests constructed from the tissue fibers with resin ducts provide similar benefits. At present, utilization of this material for nest building appears to be a value-added benefit, and not the primary reason for their removal. 
Within the forests of western Oregon, tree voles are most frequently found in Douglas-fir, occasionally in Western Hemlock, and more rarely in Sitka Spruce, and Grand Fir. Undoubtedly there have been many factors influencing the tree vole adaptation of host specificity for Douglas-fir. At the fine spatial scale of a single host tree, terpenoid resins probably influence their diet selection. This then raises the question of what role the terpene resins may play in host species selection and specificity. Our study was not designed to compare characteristics of the terpene resins among the three host species that we examined, but our results do point to potential differences that warrant further study. For example, Douglas-fir, without the removal of resin ducts, appears to be the best choice among the three species, because it provides the lowest resin concentration $(0.77 \%$ dry weight). Alternatively, Sitka Spruce appears to be the least preferred host and it was the most chemically different from the other two. It had the highest concentration of terpenoids (Table 1) with a lower monoterpene content, no sesquiterpenes, and about seven times more diterpenes than Douglas-fir and Western Hemlock (Table 2). In addition, Sitka Spruce foliage needles contain alkaloids (Gerson and Kelsey 2002) not present in the other two species that may also function as defensive chemicals (Tawara et al. 1993) or decrease palatability for the voles. Environmental effects on resin characteristics can be ruled out as causing the differences between Sitka Spruce and Western Hemlock because the trees sampled were from the same site. Sitka Spruce needles also had the most variable terpene concentrations, as would be expected for tissue with discontinuous resin ducts that vary in length and position or that occasionally may be absent (as observed for one whole needle here). The Sitka Spruce we sampled had resins only in the basal half of the needle, but Weng and Jackson (2000) found Sitka Spruce trees with resin ducts only in the apical half of needles, and others with ducts that extended the entire needle length. Whether there is enough variability among spruce trees in the proportions of their needles without resin ducts, including those with no resin ducts in any of the needles (Weng and Jackson 2000), to influence host selection by voles would be an interesting possibility to explore.

\section{Acknowledgments}

Funding and in-kind support for this study was provided by the USDA Forest Service, Pacific Northwest Research Station. For care and handling of captive voles we followed the guidelines approved by the American Society of Mammalogists (http://www. mammalogy.org/committees/index.asp). We thank E. Gerson for reviewing an earlier version of this paper.

\section{Literature Cited}

Adams, R. P. 2007. Identification of essential oil components by gas chromatography/mass spectrometry, $4^{\text {th }}$ edition. Allured Publishing Corp., Carol Stream, Illinois.
Apple, M., K. Tiekotter, M. Snow, J. Young, A. Soeldner, D. Phillips, D. Tingey, and B. J. Bond. 2002. Needle anatomy changes with increasing tree age in Douglas-fir. Tree Physiology 22: 129-136.

Benson, S. B., and A. E. Borell. 1931. Notes on the life history of the red tree mouse Phenacomys longicaudus. Journal of Mammalogy 12: 226-223.

Clifton, P. L. 1960. Biology of the dusky tree mouse. M.A. thesis, Walla Walla College, Walla Walla, Washington.

Dearing, M. D., W. J. Foley, and S. McLean. 2005. The influence of plant secondary metabolites on the nutritional ecology of herbivorous terrestrial vertebrates. Annual Review of Ecology, Evolution and Systematics 36: 169189.

Forsman, E. D., E. C. Meslow, and H. M. Wight. 1984. Distribution and biology of the spotted owl in Oregon. Wildlife Monographs 87: 1-64.

Forsman, E. D., R. G. Anthony, and C. J. Zabel. 2004. Distribution and abundance of red tree voles in Oregon based on occurrence in pellets of northern spotted owls. Northwest Science 78: 294-302.

Gerson, E. A., and R. G. Kelsey. 2002. Piperidine alkaloids in Sitka spruce with varying levels of resistance to white pine weevil (Coleoptera: Curculionidae). Journal of Economic Entomology 95: 608-613.

Graham, S. A., and G. W. Mires. 2005. Predation on red tree voles by owls and diurnal raptors. Northwest Naturalist 86: 38-40.

Gwinner, H., and S. Berger. 2005. European starlings: nestling condition, parasites and green nest material during the breeding season. Journal of Ornithology 146: 365-371.

Hamilton, W. J., III. 1962. Reproductive adaptations of the red tree mouse. Journal of Mammalogy 43: 486-504.

Howell, A. B. 1926. Voles of the genus Phenacomys. North American Fauna No. 48

Iason, G. 2005. The role of plant secondary metabolites in mammalian herbivory: ecological perspectives. Proceedings of the Nutrition Society 64: 123-131.

Iason, G. R., and J. J. Villalba. 2006. Behavioral strategies of mammal herbivores against plant secondary metabolites: the avoidance-tolerance continuum. Journal of Chemical Ecology 32: 1115-1132.

Kimball, B. A., D. L. Nolte, R. M. Engeman, J. J. Johnston, and F. R. Stermitz. 1998. Chemically mediated foraging preference of black bears (Ursus americanus). Journal of Mammalogy 79: 448-456.

Langenheim, J. H. 2003. Plant resins: chemistry, evolution, ecology, and ethnobotany. Timber Press, Inc., Portland, Oregon.

Maser, C. 1998. Mammals of the Pacific Northwest: from the coast to the high Cascades. Oregon State University Press, Corvallis, Oregon.

Maser, C. O., B. R. Mate, J. F. Franklin, and C. T. Dyrness. 1981. Natural history of Oregon coast mammals. U.S. Department of Agriculture, Forest Service General Technical Report PNW-133.

Radwan, M. A., G. L. Crouch, C. A. Harrington, and W. D. Ellis. 1982. Terpenes of ponderosa pine and feeding preferences by pocket gophers. Journal of Chemical Ecology 8: 241-253.

Snyder, M. A. 1992. Selective herbivory by Abert's squirrel mediated by chemical variability in ponderosa pine. Ecology 73: 1730-1741.

Sorensen, J. S., J. D. McLister, and M. D. Dearing. 2005. Plant secondary metabolites compromise the energy budgets 
of specialist and generalist mammalian herbivores. Ecology 86: $125-139$.

Stamp, N. 2003. Out of the quagmire of plant defense hypotheses. Quarterly Review of Biology 78: 23-55.

Swingle, J. K. 2005. Daily activity patterns, survival, and movements of red tree voles (Arborimus longicaudus) in western Oregon. M.Sc. thesis, Oregon State University, Corvallis.

Taylor, W. P. 1915. Description of a new subgenus (Arborimus) of Phenacomys, with a contribution to knowledge of the habits and distribution of Phenacomys longicaudus True. Proceedings of the California Academy of Sciences (Series 4) 5: 111-161.

Tawara, J. N., A. Blokhin, T. A. Foderaro, F. R. Stermitz, and H. Hope. 1993. Toxic piperidine alkaloids from pine (Pinus) and spruce (Picea) trees. New structures and a biosynthetic hypothesis. Journal of Organic Chemistry 58: 4813-4818.

Vaughan, T. A. 1982. Stephens' woodrat, a dietary specialist. Journal of Mammalogy 63: 53-62.
Vourc'h, G., J. Russell, and J.-L. Martin. 2002. Linking deer browsing and terpene production among genetic identities in Chamaecyparis nootkatensis and Thuja plicata (Cupressaceae). Journal of Heredity 93: 370-376.

Walker, A. 1928. Some Oregon Phenacomys. Journal of Mammalogy 4: 254-255.

Walker, A. 1930. Notes on the forest Phenacomys. Journal of Mammalogy 11: 233-235.

Weng, C., and S. T. Jackson. 2000. Species differentiation of North American spruce (Picea) based on morphological and anatomical characteristics of needles. Canadian Journal of Botany 78: 1367-1383.

Wooster, T., and P. Town. 2002. Newly discovered food and habitat use by California red tree voles. California Fish and Game 88: 181-185.

Zahler, P., and M. Khan. 2003. Evidence for dietary specialization on pine needles by the woolly flying squirrel (Eupetaurus cinereus). Journal of Mammalogy 84: 480-486.

Received: 25 November 2008

Accepted: 3 June 2009 